\title{
Evaluation of Teaching Materials in Writing Literature Text at SMPIT Masjid Syuhada Yogyakarta
}

\author{
Hanifah Nurunnikmah* \\ Graduate School \\ Universitas Negeri Yogyakarta \\ Yogyakarta, Indonesia \\ hanifahnurunnikmah.2018@student.uny.ac.id
}

\author{
Tadkiroatun Musfiroh \\ Graduate School \\ Universitas Negeri Yogyakarta \\ Yogyakarta, Indonesia \\ tadkiroatun@gmail.com
}

\begin{abstract}
This study aims to determine the results of evaluation for teaching materials used by teachers to implement literary writing skills learning in the 2013 curriculum at Syuhada Junior High School.

This study uses a qualitative approach with a description method. The population in this study were students of class VII, VIII, and IX SMPIT Masjid Syuhada. The data is sampled using a random sampling technique. Data collection techniques using the method of documentation, questionnaires, and interviews. The analysis uses data reduction which is then classified.

The results showed that: (1) most of the teachers didn't use special module for teaching how to write literature, (2) evaluation of learning outcomes provided to students in writing literary texts by means of student appreciation, intensive assistance, and material reflection, and (3) the role of the teacher as an implementer, evaluator, and planner is sufficient with the existing teaching material, but more quality and specific teaching materials are needed for learning to write literature at SMPIT Masjid Syuhada Yogyakarta. A collaboration between teacher who design a simple yet practical teaching material, and students as an acquired data that helps to improve the quality of the teaching material.
\end{abstract}

Keywords - writing literature, teaching material, evaluation

\section{INTRODUCTION}

A change in curriculum depends on the actuality and the need to support the learning ability of the students. A new horizon has appeared since the scientific approach takes place in the new curriculum, setting the Curriculum of the Unit Stage of Education (KTSP) aside. It's turning the approach from once a competency-based into scientificbased, which aims to enhance more ability on creativity, especially on Indonesian Literature subject.

The Indonesian Literature subject has goals that its students can possess an effective and efficient communication ability according to the ethics, either verbal or through writing, with the main goal is to appreciate and proudly using the Indonesian Language as the National Language and the language of unity in various purposes. The Indonesian Literature subject is using a text-based approaches in the 2013 curriculum (Pinasti, 2018:156).

Currently, there are flaws in the text-based education, either in its concept or in the implementation by the teachers. It is an urgent matter, yet an interesting subject to be learned about the evaluation of the 2013 curriculum, especially related with the planning and implementation of the lesson and examination (Jaedun, Hariyanto, etc., 2014:15).

The Regulation of Education and Cultural Ministry (Permendikbud) No.53, 2015 article 1 stated that the evaluation of the learning process by the teachers is a process of acquiring the information/data about the learning process of the students in several aspects such as attitude, knowledge, and psychomotor which were planned and systematically carried out through assignments and tests, to observe the process, advancement, and the evaluation of the students' learning process. The eighth article of the regulation stated an interesting point about the assessment on attitude which stated that the assessment of the attitude is done through the observation as the main source of information and the teacher is at full responsibility on the report.

A teacher needs to consider several conditions regarding the evaluation of the teaching materials, such as the low literation level of the students that disables them from understanding the given subject, the utilization of technology in assessing the learning process from the teaching materials, and the curriculum itself that seems to be roughly enforced.

Rizaldi (2017:167) stated that choosing an appropriate textbook for the teaching environment is crucial. This is likely the common problem for the teachers. Teaching with the textbooks requires an understanding of the textbook itself to find the merit and demerit of the teaching material.

Purwanti (2019:108) stated that teachers should be able to establish various methods and materials which developed according to the students' need and has the purpose to analyze the need of the environment. Sometimes it is problematic for the teacher to find the appropriate textbook for language courses.

Wodrow (2017:53) claims that on of the elements used in an effective language teaching is to give the students the right subject material, and to adjust the materials 
between what is needed to be done and what the instruction is saying about.

According to the background above, the writer decides several issues to be addressed, as follows: (1) are the teachers using teaching materials, such as textbook for the literature course in the 2013 curriculum. (2) is the teaching material suits the writing competence of the students in the 2013 curriculum. (3) how the assessment of the course from the development of the teaching material is done in the 2013 curriculum.

The teaching material, in particular the one for the language course needs an evaluation to adjust the indicator of competency that is needed by students to pass through, especially on literature text writing subject. Putri and Diah showed that textbook is a teaching material that used a more user-friendly language. A textbook also contains assessments in every last part of a subject, chapter, or semester (Yarmi, 2014:9). Therefore, every student needs a textbook in every literature text courses.

Literature text is a product of human's creativity. This creative work can take form in imaginative or synthesis thinking that create a new pattern or correlation. Many people hope that the writing of literature become the final product of educational process. This argument was based on scientific assumption that writing involve and moves various pedagogic psychology components. Therefore, writing leads to the knowledge and thinking pattern on how an idea can be developed into a story. But the development of the story itself have to come in harmony with the cognitive-affective development of the students.

Sulkifli (2016:4) stated that in cognitive and psychomotor aspect, the students were required to follow the learning process which based on mastering competence at desired point by paying attention characteristic of the content competency itself where knowledge is a final product. On the affective aspect, the student's ability to comprehend more complicated content is developed, and thus means that an indirect education is required. There was assumption that someone's attitude can be influenced by his knowledge. Thus, the result from the affective learning is barely visible, and there is a direct relation between attitude (affective) and knowledge (cognitive).

The assessment on student's development, especially on writing abilities is need to be fluently trained in order to achieve the competence. To meet such a level, someone needs to practice frequently. Writing is not about moving hands or knowing the techniques, but writing is about telling readers something that the writer know and more than that, to help the readers understand thoroughly about a topic that they already know.

Writing ability can increase the confidence and helps to emerge the creativity. Writing is not merely a motoric aspect but also involved the mental state of the writer. Writing is known as form of communication media. Through writings, someone can convey a meaning, idea, thoughts, and feelings by combining a series of words and sentences. Therefore, writing always related to the evaluation done by teacher as an instrument of learning assessment.
The evaluation process on language learning is to gather, analyze, and interpreting the information about the entire learning process based on the information transfer rate and the score rate of the student on the current learning system. Mahirah (2017:257) claims that Evaluation have the ability to motivate the students to study more and encourage the teachers to improve their teaching quality, as well as to encourage the school to improve their facilities and overall quality. Evaluation is divided into five fundamental components, as follows: (1) articulating the goal of an education system, (2) identify and gathering relevant information, (3) possess a valuable idea and beneficial to the students in their life and professions, (4) to analyze and interpret the information for the students, and (5) class management or decision making.

The teaching and learning process evaluation become an issue for the teachers to reflect the delivered subject within the teaching process and for the student to improve their critical thinking capability on developing story idea until it makes a whole complete story. Assessment with a written test have not reach a certain correlation between the theory and practical competence of the students, according to the approach and method used. Kerta (2015:219) stated that Synchronization between teaching, learning process, and the evaluation of them both mostly depended on single instrument, a written test that carried out on daily test, a National Exam (UN), and Post-Semester Test (PAS). In written test, normally there's no issues as long as the parameter is about cognitive aspect. But in reality, various studied subjects were involving not only cognitive aspect, but also affective and psychomotor aspect, like literature studies. Thus, the teaching of literature subject is depended on the teaching material given to the students.

Teaching material is an absolute instrument needed by the teacher to implement the subjects suitable for the students within the course. Literature texts definitely help students in exploring the expression of meaning and feels that embodied in a form of a writing. But in reality, the teaching material still need a development in its aspects of media, method, and subject expertise in order to be used to improve the writing ability. Therefore, an individual instrument regarding to the teaching material is required in order to know the students' development in their achievements on literature studies. This research aims to know the effectivity of the teaching material that is used by the teachers towards the ability to write literature texts.

According to the explanation above, the writer make hypotheses as follows: (a) there are no particular textbook that can be used as a teaching material for literature course in the 2013 curriculum. (b) a synchronization of the teaching material with the literature text writing competency in the 2013 curriculum. (c) there is visible outcome of the students in the development of the teaching material in the 2013 curriculum.

\section{METHODOLOGY}

This research using qualitative approach with a descriptive method to explains about the evaluation of the teaching material development in SMPIT Masjid Syuhada. 
Creswell (2008:176) explained that the grounded theory exist from connecting several variables and modify them according to the participants' perspective.

The data were collected by questionnaire and interview. Bogdan and Biklen (2007:20) stated that descriptive is the character in the qualitative research because the materials were taken from documents, recordings, transcripts, etc. This research also categorized as the research design of qualitative research because the goal of this research is to examine the quality and to find out the plus and the minus criteria of a teaching material.

The data analysis is using description which discuss about the purpose and assessment indicator that is acquired from the course when using the designated teaching material. Cunningsworth $(1995: 25)$ stated that the procedure of the data analysis is consisted of three phases. First, become familiar with the data, in form of the textbooks, and classify them by scanning the data and other sources. Second, comparing the teaching material with the syllabus of Bahasa Indonesia in the first semester according to the 2013 curriculum, revised version of 2017. Third, making a conclusion and analyze it according to the evaluation criteria of Bahasa Indonesia textbook.

Data verification is using the teacher's materials, such as main guidebook, and supplementary books that been used in the course to determine the plus and the minus before it developed into teaching material or supplementary textbook. Cohen (2012:207) claimed that one of the triangulation methods is the time triangulation as a method to define the change and process factors by utilizing the cross-sectional and longitudinal designs.

\section{RESULT AND DISCUSSION}

\section{A. Results}

1. Guidebook

Within the research period, the writer had observed that all teacher in SMPIT Masjid Syuhada were using a guidebook titled Bahasa Indonesia, published by the Ministry of Education and Culture of Indonesia and exercise book as a complementary material published by Erlangga. The advantage of the guidebook is that the book contains various concept on the subject as well as the explanation. But the disadvantage is that the book contains less exercises so that the students have a limited access to practice on a related subject. On the contrary, the plus point of an exercise book is that it contains various exercises, but lacking in subject material itself.

\section{Evaluation of the Result}

The evaluation of the teaching material was carried out on the guidebook and complementary book and resulting in a score of 74, which means that the books are considered as appropriate and contain enough materials to be given to the students. The teaching guide itself need to be improved, so that a suitable subject is given to the students in every course, according to their level of competence. The evaluation technique used by the teacher as the planner, the executor, and evaluator of the learning process must be involving several steps and methods.
The 2013 curriculum aspects become a defining point on the assessment of the teaching material, especially on how the teacher give the lessons with a scientific approach implemented on it. Every teaching material used was possessed its plus and minus points. The main guidebook mostly delivers a more packed subjects to be studied by the students, while the exercise book provides more exercises to examine the students understanding and practical capabilities on a certain subject of the course.

The utilization of particular guidebook also beneficial to be an integrated teaching material, in a form of simple guidebook or subject resume, adjusted to the individual capability of the students. The teaching material contained the theory of writing, various kind of literature texts, procedures of writing, examples of literary works, and the lingual rule within a literature text. One of the Bahasa Indonesia teacher said that in order to fluently capable to write, an individual adjustment is indispensable. On the contrary, the material given to the students particularly haven't met the requirement to be used.

The implementation of guidebook and resume resulting in drill exercise taken by the students with an average score of 85 , which categorized as a good result. Other than that, the guidebook helps students on writing their literature texts, which priorly was considered to be burdening but later considered as a fun activity. The teacher evaluates the students' result using the guidebook by recording their improvement in writing the framework of a literature text. If there was a failure in several aspects of the subject, the student will get a remedial in order to motivate them to write much better. The evaluation procedure of the teaching material was carried out through the peer discussion between the teachers, reflection on the content, and guiding the students who lacking the ability to write according to the literature standards.

\section{The Role of the Teacher}

According to the result of the research, it can be concluded that all the teachers had reached score of 95 which considered as successful according to the indicators where the teacher successfully implement the teaching material on the students. There are several considerations related to the framework of the learning process that designed to examine the result of the existing teaching materials and the succession rate of the students on a certain capability.

\section{B. Discussion}

According to the result of the research, we can see that the assessment on the teaching material needs to be improved. The available teaching material and the method used were influential to the development of the students' writing ability, and their capability to turn idea into an appropriate writing. All teachers were using 2013 curriculum where the school direct the students to use scientific approach and active learning inside the classroom. Therefore, the outcome of students' writing skill in literature text was considered good enough by the fact that they improve their creativity, even though there were still several procedures needed to develop a more structured writing. 
Teaching guide have its pros and cons, the primary and complementary guidebook become the main instrument in literature course. The concept is that the primary guide is used to thoroughly understand the literary writings. The complementary guide is used to practicing and examining the students' learning through a textual exercise based on the concept and theory prior to the learning, so that the students become stimulated in their effort to practicing their writing ability. In particular module implementation scope, teachers have not designed an online teaching guide or the similar kinds which actually are more integrated and more flexible to meet the standards of teaching in a modern era. The teachers are using the resume which composed from the literature concept and theories, as an instrument to examine their teaching guide which then later used to improve their students' ability in writing.

In the scope of the content material, every teacher had their techniques and methods to teach how to create a proper writing framework as well as the story building itself. But the substance is similar to the method of starting with the concept of literature, the explanation and description of the structure, lingual rule, and the example. A teacher needs an adjustment of his model and method that suitable for the students' individual competence. The guidebook had showed its capability to help students to improve their ability in literature writing because there is a drill exercise so that the students have numerous attempts on practicing their writing.

In evaluation scope about the relation between the students and teaching guide, the teachers carried out the evaluation in the end of a course by seeing the final framework written by the students. Other than that, the teachers create a discussion forum and peer review for the writings so that the students can make some correction on the visible mistakes in lingual rule and other parameters in writing. The evaluation for the teaching guide was carried out by sharing the experience between the teachers and giving a special course for the students who still failing in literature writing. Also, the teachers always review their subject which then improved into more proper teaching guide that can be used to enhance the students' capability on writing a literature text.

\section{IV.CONCLUSION}

This research resulting in several important points related with the arrangement of a new teaching guide. There are three important components that need to be concerned, in order to create a subject matter that suitable for the development of the students competence, as follows: (1) most of the teachers have not used a particular guide in their teachings, especially in literature writing. (2) evaluating the students' progression in literature writing by giving them appreciation, intensive guide, and reflection of the subject. (3) the role of the teacher as a planner, executor and evaluator have reached the standard by improving their teaching quality, a cooperation between the teachers in creating a more effective teaching guide and the treatment towards the students as a variable that later be used to improve the quality of the teaching guide.

\section{REFERENCES}

Pinasti, I. R. (2018). Pembelajaran Bahasa Indonesia Berbasis kurikulum 2013 (Studi Kasus Pembelajaran teks ulasan cerpen di kelas VIII SMP Negeri 2 Ngawi). Basastra, 6, 155-167.

Jaedun, A., Hariyanto, V. L., Nuyadin., \& E.R. (2014). An evaluation of the implementation of Curriculum 2013 at the building construction department of vocational high schoos in Yogyakarta. Education, 7, 1422.

Kemendikbud. (2013b)

Hanifa, R. (2017). EFL Published Materials: An Evaluation of English Textbooks for Junior High School in Indonesia. Advances in Language and Literary Studies, 9, 167-173.

Purwanti, R. A. (2019). Evaluation on an ESP Course Book: Get Along with English for the Hotel Industry. English Educator Society, 4, 107-116

Woodrow, L. (2017). Introducing Course Design English for Specific Purposes ( $1^{\text {st } e d .) . ~ G r e a t ~ B r i t a i n: ~ R o u t l e d g e, ~ T a y l o r ~ \& ~ F r a n c i s ~ G r o u p . ~}$

Yarmi, G. (2014). Meningkatkan Kemampuan

Menulis Kreatif Siswa Melalui Pendekatan Whole Language Dengan Teknik Menulis Jurnal. Perspektif lmu Pendidikan, 28, 9-16.

Sulkifli, Mawarti. (2016). Kemampuan Menulis Puisi Siswa Kelas VIII Smp Negeri Satu Atap 3 Langgikima Kabupaten Konawe Utara. Bastra, 1, 122.

Mahirah, B. (2017). Evaluasi Belajar Peserta Didik (Siswa). Education Management, 1, 257-267.

Kerta, A. M. (2015). Asesmen Otentik dalam Pembelajaran Sastra: Suatu Kajian Pustaka. Aksara, 27, 217-227.

Creswell, J. W. (2008). Research Design: Qualitative, Quantitative,mixed methods approaches ( $3^{\text {rd }}$ ed.). (Fawaid, Achmad.,Trans.). Yogyakarta: Pustaka Pelajar (original work published 1998).

Bogdan, R.C., \& Biklen, S. K. (2007). Qualitative Research for Education: an Introduction to Theories and Method (4th ed.). New York, NY : Pearson Education Group.

Cunningsworth, A. 1995. Choosing Your Coursebook. Oxford : Macmillan Heinemann

Cohen, L. (2012). Research Method in Qualitative. New York, NY: Pearson Education Group. 